\title{
Efficiency of sanitary management of litter in Eimeria spp. control in poultry housing of Western Paraná, Brazil
}

\author{
Eficiência dos manejos sanitários de cama no controle de Eimeria spp. em \\ aviários no Oeste do Paraná, Brasil
}

\author{
André Luis Vriesman Beninca1* (D); Ana Paula Molinari Candeias ${ }^{1}$ (D); Sérgio Rodrigo Fernandes² (1); \\ Nelson Luis Mello Fernandes ${ }^{3}$ (D)
1 Programa de Pós-graduação em Ciências Veterinárias, Universidade Federal do Paraná - UFPR, Palotina, PR, Brasil ${ }^{2}$ Departamento de Zootecnia, Universidade Estadual de Londrina - UEL, Londrina, PR, Brasil ${ }^{3}$ Departamento de Ciências Veterinárias, Universidade Federal do Paraná - UFPR, Palotina, PR, Brasil

How to cite: Beninca ALV, Candeias APM, Fernandes SR, Fernandes NLM. Efficiency of sanitary management of litter in Eimeria spp. control in poultry housing of Western Paraná, Brazil. Braz J Vet Parasitol 2021; 30(2): e026920. https://doi.org/10.1590/ S1984-29612021039

\begin{abstract}
The objective of this research was to evaluate the control of coccidiosis in the litter of commercial poultry housing in the Western region of Paraná, Brazil, which adopts sanitary management to control Salmonellosis. Three litter treatments were selected, proposed by an integrating company in the region: fermentation associated with liming (FL); liming (L) and fermentation (F). Stool samples were collected from 18 poultry housing, in a completely randomized experimental design, testing different collection areas in the sheds, from the $5^{\text {th }}$ day of the birds' housing, repeated weekly until the $40^{\text {th }}$ day, during five successive flocks. The incidence of coccidiosis was determined by oocysts count in feces (O०PG), testing the interactions between treatment, age of birds and the number of flocks housed. Samples were selected to identify, through the Multiplex PCR, species of the genus Eimeria. circulating in the shed. The results showed that in litter where fermentation was adopted, the efficiency to control the sporulation of Eimeria spp. was significantly $(p<0.05)$ higher than in the other treatments. The use of the Multiplex PCR technique requires improvements in the preparation of samples for the extraction of genetic material.
\end{abstract}

Keywords: Eimeria spp., oocysts, sanity, fermentation, liming, Multiplex PCR.

\section{Resumo}

O objetivo deste trabalho foi avaliar a eficiência dos manejos sanitários aplicados à cama de aviários comerciais para o controle da salmonelose nas criações de frango de corte, na região Oeste do Paraná, e verificar seu efeito no controle da coccidiose. Foram selecionados três tratamentos de cama: a fermentação associada à calagem (FL); calagem (L) e fermentação (F). As amostras de fezes foram coletadas de 18 aviários, com um delineamento experimental inteiramente casualizado, testando-se diferentes áreas de coleta. As coletas foram realizadas a partir do $5^{\circ}$ dia do alojamento e se repetiram semanalmente até o $40^{\circ}$ dia, durante cinco lotes sucessivos. A incidência da parasitose foi determinada pela contagem de oocistos por grama de fezes (OoPG), testando as interações entre tratamento, idade das aves e número de lotes alojados. Amostras de fezes foram selecionadas para identificar os oocistos esperulados das espécies do gênero Eimeria circulantes no galpão, por meio do Multiplex PCR. Observouse que a fermentação foi significativamente $(p<0,05)$ mais eficiente, comparando-se o mesmo lote ao longo de todos os observados. A utilização da técnica de PCR Multiplex, precisa ser padronizada para amostras de campo.

Palavras-chave: Eimeria spp., oocistos, sanidade, fermentação, calagem, Multiplex PCR. 


\section{Introduction}

Poultry is a commercial activity with major importance in the global economy, where Brazil is one of the bigger providers. In 2019 exported 4.214 thousands of tons in chicken and processed (Santos et al., 2019). Poultry breeding occurs in houses with greater density during the whole productive cycle, which may induce the appearance of infectious and parasitic diseases (Peek \& Landman, 2011), such as coccidiosis. Enteric disease caused by intracellular protozoan parasite of the genus Eimeria, Infraphylum Apicomplexa (Ruggiero et al., 2015), includes seven species: Eimeria acervulina, Eimeria brunetti, Eimeria tenella, Eimeria maxima, Eimeria mitis, Eimeria necatrix and Eimeria praecox. (Urquhart et al., 1998; Kawazoe, 2009). The oocysts are eliminated with feces and may infect other animals by ingesting sporulated oocysts.

The clinical manifestation of the disease represents less than $5 \%$ of the cases, with clinical signs such as: diarrhea, bloody excreta, apathy, oligodipsia and inappetence, while subclinical infections comprise $20 \%$ of the cases, being the biggest responsible for losses in productivity (Zhang et al., 2013). It is a disease that causes great financial impact on the activity (Gazoni et al., 2020), the replication of the protozoan in the enterocytes causes lesions, which predisposes to the occurrence of bacterial enteritis such as Salmonella typhimurium, Campylobacter and Clostridium perfringens (MacDonald et al., 2019; Rimet et al., 2019; Adhikari et al., 2020).

The production of broilers is currently carried out in sheds with a controlled environment and shavings are the most used bedding in commercial poultry in the Western region of Paraná, Brazil, due to their great availability and low cost. The litters are used for up to six consecutive flocks, varying according to the protocol adopted by the industry, for this, sanitary measures are adopted during the sanitary cleaning between flocks, with the objective of reducing the contamination of the environment for broiler birds. The most widely used methods among companies are fermentation and liming, with the possibility of combining both.

The objective of this study was to determine whether the combination of litter management adopted with the aim of controlling Salmonella is efficient for the control of coccidiosis, in addition to standardizing a protocol for the recovery, extraction and purification of Eimeria from stool samples, collected in litter.

\section{Material and Methods}

This work was carried out in accordance with the Ethical Principles of Animal Experimentation, adopted by the National Council for Animal Experimentation Control (CONCEA) and was approved by the Ethics Committee on the Use of Animals in the Palotina Sector, under protocol n 38/2019.

Fresh stool samples were collected directly from the litter of commercial poultry housing in the Western region of Paraná, Brazil. The experimental design was completely randomized (DIC) with three treatments and six replications, corresponding to the poultry housing. The interaction between OoPG with treatment, age, collection points in the poultry housing and the number of production cycles was analyzed, in addition to all interactions involving the different treatments and the used cycles. A total of 1,606 samples was collected at different points distributed along the shed, divided into 3 regions: next to the evaporative plates (P1), in the middle of the shed (P2) and close to the exhaust fans (P3). In each region (P) feces were collected several times, totaling a pool of approximately $200 \mathrm{~g}$ of fresh feces. As collections started from the $5^{\text {th }}$ day of life, repeating weekly until the $40^{\text {th }}$ day of bird lives. The treatments were: (FL) fermentation treatment associated with liming; (L) liming; and (F) fermentation, which were necessary in the interval between flocks, after the removal of the birds for slaughter. The fermentation process was executed between flocks, during 15 days, where the litter was kept covered with canvas during 12 days, and scattered after this time. The liming process made by adding $800 \mathrm{~g} / \mathrm{m}^{2}$ of calcium oxide $(\mathrm{CaO})$ to the litter mixed three times a day for 10 days. All the animals were treated with an association of nicarbazin and narasin (100ppm) beginning by $1^{\text {st }}$ to $28^{\text {th }}$ day of life, followed by salinomicin from $29^{\text {th }}$ to $38^{\text {th }}$ day in $66 \mathrm{ppm}$ thru ration.

The oocysts were identified by Gordon \& Whitlock (1939) modified technique (OoPG), observing the morphological structures in McMaster slide by optical microscopy. During this process different species were observed and visual identification is not the most reliable option to determinate witch are those, there are small morphological differences between the oocyst that cannot be stated visually; therefore use of PCR is much more reliable technique in order to determine the present species.

The parameter adopted to judge the interaction between the variables analyzed was the count of oocysts per gram of feces, using the modified Gordon technique. Samples with OoPG equal to or greater than $5.0 \times 10^{3}$ were selected to identify the species of the genus Eimeria circulating through the Multiplex PCR. Oocyst recovery was 
performed from $5 \mathrm{~g}$ of sample diluted in $60 \mathrm{~mL}$ of $\mathrm{NaCl}$ solution $\left(\mathrm{d}=1.18 \mathrm{~g} / \mathrm{cm}^{3}\right)$. Samples were clarified according to Tang et al. (2018) and extraction with phenol-chloroform, according to Sambrook et al. (1989). The selected primers and the Multiplex PCR protocol followed as described by Carvalho et al. (2011). For amplification, 2 mixes were adopted with the specific primers for the prevalent Eimeria species, being: mix 1 (E. acervulina, E. brunetti, E. mitis and E. maxima) and, mix 2 (E. tenella, E. necatrix and E praecox). For amplification, reactions were conducted in a total volume of $25 \mu \mathrm{L}$ with $17.5 \mu \mathrm{L}$ Green Master Mix® (Promega), $0.5 \mu \mathrm{L}$ of each primer $(50 \mathrm{pmol} / \mu \mathrm{L}), 1 \mu \mathrm{L}$ of the sample and the rest with DNase-free water. For positive control, a commercial vaccine Biococcivet R® (Biovet) containing seven species of Eimeriaas followed: E. acervulina, E. brunetti, E. tenella, E. maxima, E. mitis, E. necatrix and E. praecox was used, while the negative control was consisted with water. Electrophoresis was carried out on $2.5 \%$ agarose gel, in $90 \mathrm{~mA}$ for one hour and stained in ethidium bromide (EtBr) solution for 15 minutes.

The statistical analyses were performed in the Statistical Analysis System (SAS), version 9.0 (SAS Institute, 2002). The distribution of OoPG data was analyzed by the Shapiro-Wilk test (PROC UNIVARIATE), which indicated that the data was not adjusted to a normal distribution. Thus, the OoPG data were subjected to logarithmic transformation $\left[\log _{10}(x+1)\right]$ and then analysed in a mixed model with repeated measures in time (PROC MIXED). The effects of litter treatment, flock, age and sampling point, and the interactions litter treatment $\times$ age, litter treatment $\times$ flock, flock $\times$ age, litter treatment $\times$ sampling point, and litter treatment $\times$ flock $\times$ age were the fixed effects; and aviary nested within farmer and litter treatment was the random effect in the model. The most appropriate covariance structure for the variable analyzed was defined according to the corrected Akaike (AICC) and Bayesian (BICC) information criteria. The means were compared by Tukey test (LSMEANS statement). The significance level of 0.05 was adopted in all analyses performed. Towards an appropriate interpretation, the results were presented as mean and standard error of the non-transformed OoPG data.

\section{Results}

A total of 1,606 fecal samples were collected during five consecutive flocks, within the three points of collection, from 18 poultry housing in 330 days. All the effects and interactions were significant, in exception of collection points, such as represented in Table 1.

Table 1. Fixed effects and their interactions on the OoPG of feces samples collected from broilers housed in commercial aviaries in the Western region of Paraná, Brazil.

\begin{tabular}{cc} 
Effects & $P$-value \\
\hline Litter treatment & 0.0006 \\
Flock & $<0.0001$ \\
Sampling point & 0.0897 \\
Age & $<0.0001$ \\
Litter treatment $\times$ Age & $<0.0001$ \\
Litter treatment $\times$ Flock & $<0.0001$ \\
Flock $\times$ Age & $<0.0001$ \\
Litter treatment $\times$ Sampling point & 0.5143 \\
Litter treatment $\times$ Flock $\times$ Age & $<0.0001$ \\
\hline
\end{tabular}

Data were weekly measured, resulting in six collections per flock. The OoPG counting was used as a parameter to determine the number of oocysts of the genus Eimeria shedding by the chicks. Initially, in this experiment, there was a low amount of oocysts shedding by birds at the $5^{\text {th }}$ day of life $\left(13-2,118\right.$ oocysts). Between the $5^{\text {th }}$ and $22^{\text {th }}$ days, they were stabilized (81-1,824 oocysts). From those days on, there was an increase of OoPG within 24-32 $2^{\text {th }}$ days $(3,833-13,216$ oocysts) identified as the peak for Eimeria, followed by a decrease, the average numbers per period are described in Table 2 and represented in (Figure 1). 
Table 2. Average OoPG value in feces samples collected at each broilers age in commercial aviaries where different sanitary treatments were applied to the litter.

\begin{tabular}{lcccccc}
\hline \multirow{2}{*}{ Treatment $^{\prime}$} & \multicolumn{5}{c}{ Age (days) } \\
\cline { 2 - 7 } & $\mathbf{5 - 8}$ & $\mathbf{1 2 - 1 5}$ & $\mathbf{1 7 - 2 2}$ & $\mathbf{2 4 - 2 9}$ & $\mathbf{3 2 - 3 8}$ & $\mathbf{3 9 - 4 5}$ \\
\hline $\mathrm{FL}$ & $13^{\mathrm{Ad}}$ & $1408^{\mathrm{Ac}}$ & $1801^{\mathrm{Ab}}$ & $13216^{\mathrm{Aa}}$ & $8613^{\mathrm{Aa}}$ & $8690^{\mathrm{Aa}}$ \\
Liming & $2118^{\mathrm{Ab}}$ & $316^{\mathrm{Ab}}$ & $1824^{\mathrm{Ab}}$ & $7256^{\mathrm{ABa}}$ & $5936^{\mathrm{Aba}}$ & $9971^{\mathrm{Aa}}$ \\
Fermentation & $254^{\mathrm{Ac}}$ & $81^{\mathrm{Ac}}$ & $1269^{\mathrm{Ac}}$ & $3833^{\mathrm{Bb}}$ & $4812^{\mathrm{Bb}}$ & $9801^{\mathrm{Aa}}$ \\
\hline
\end{tabular}

'FL: fermentation + liming. Uppercase letters compare treatments within each age, and lowercase letters compare ages within each treatment by Tukey test $(p \leq 0.05)$.

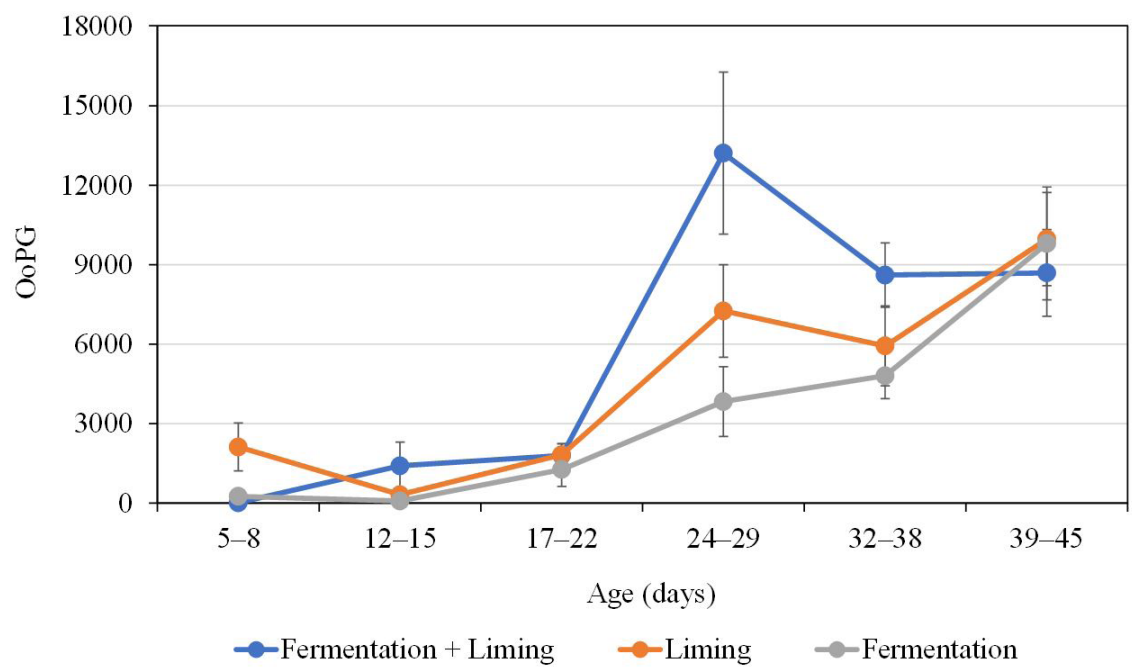

Figure 1. Dynamics of Eimeria spp. oocysts excretion in broilers housed on litter subjected to different sanitary treatments in commercial aviaries in the Western region of Paraná, Brazil.

Collection points were visually different between the areas although they were considered with tendency to significance to elimination of OoPG values $(p=0,0897)$, but it was not a major point of influence in Eimeria oocysts distribution in the housing.

Considering the interactions between treatments and flock, was be observed reduction of OoPG over time (Figure 2) where FL had the most significant OoPG during the whole period, the OOPG rise in the second flock

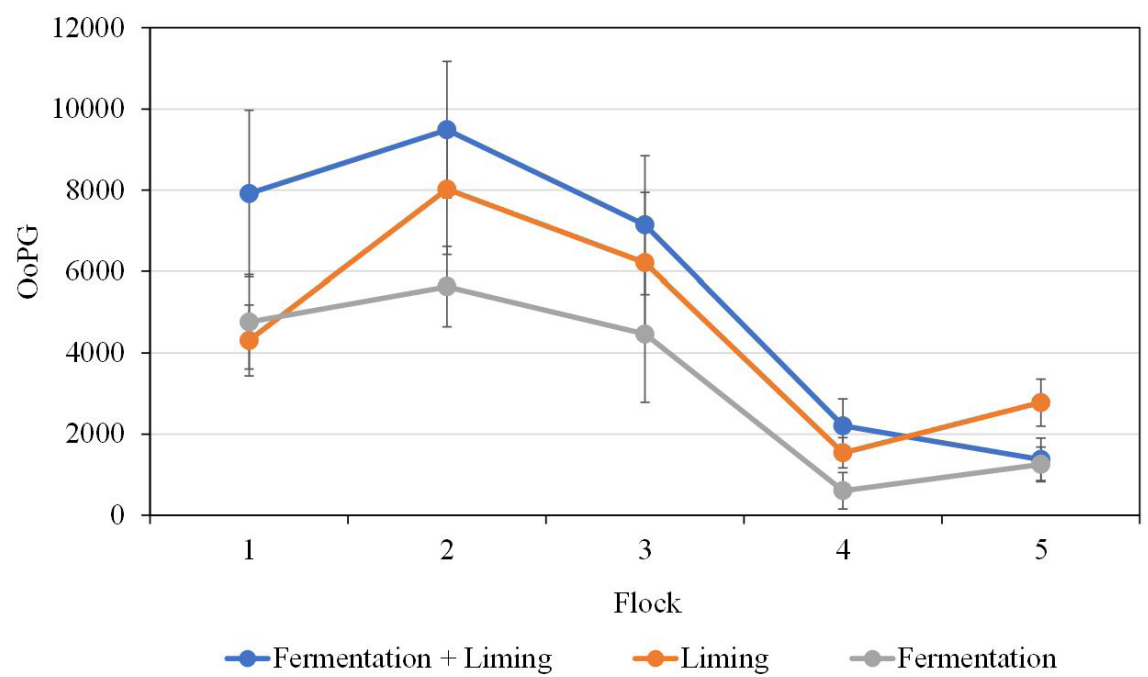

Figure 2. Dynamics of Eimeria spp. oocysts excretion in broiler flocks housed on litter subjected to different sanitary treatments in commercial aviaries in the Western region of Paraná, Brazil. 
was assigned to climate condition such as: colder temperature, reduced air exchange and bed moisture increase (Table 3). The minimum OoPG result corresponds to the $4^{\text {th }}$ flock ( $<3 \times 10^{3}$ oocysts) almost by the end of bed usage, which happened during summer with higher temperatures and reduced moisture.

Table 3. Average OoPG value in feces samples collected in each flock housed in commercial aviaries where different sanitary treatments were applied to the litter.

\begin{tabular}{lccccc}
\hline \multirow{2}{*}{ Treatment $^{\prime}$} & \multicolumn{5}{c}{ Flock (n) } \\
\cline { 2 - 6 } & $\mathbf{1}$ & $\mathbf{2}$ & $\mathbf{3}$ & $\mathbf{4}$ & $\mathbf{5}$ \\
\hline $\mathrm{FL}$ & $7913^{\mathrm{Ab}}$ & $9486^{\mathrm{Aa}}$ & $7142^{\mathrm{Ab}}$ & $2203^{\mathrm{AC}}$ & $1374^{\mathrm{BC}}$ \\
Liming & $4307^{\mathrm{Ab}}$ & $8019^{\mathrm{Aa}}$ & $6208^{\mathrm{Ab}}$ & $1538^{\mathrm{Ad}}$ & $2777^{\mathrm{AC}}$ \\
Fermentation & $4760^{\mathrm{Ab}}$ & $5628^{\mathrm{Aa}}$ & $4464^{\mathrm{Ab}}$ & $604^{\mathrm{Bd}}$ & $1254^{\mathrm{BC}}$ \\
\hline
\end{tabular}

'FL: fermentation + liming. Uppercase letters compare treatments within each flock, and lowercase letters compare flocks within each treatment by Tukey test $(p \leq 0.05)$.

The average Eimeria oocysts production related to treatments interacting with flocks and age groups are represented ( $F L$, L and F) in Table 4 where FL had the major number of oocysts per gram of feces, mostly considering the peak between the $24^{\text {th }}-29^{\text {th }}$ days, then numbers reduced. $L$ and $F$ proved to be more efficient, with lower peak and reduced OoPG during all the flocks studied, specially $\mathrm{F}$ (Figure 3a, 3b and 3c).

Table 4. Interaction between age and flock on the average OoPG value in feces samples collected within each sanitary treatment applied to the litter in commercial aviaries.

\begin{tabular}{|c|c|c|c|c|c|c|c|}
\hline \multirow{2}{*}{ Treatments } & \multirow{2}{*}{ Flock } & \multicolumn{6}{|c|}{ Age (days) } \\
\hline & & $5-8$ & $12-15$ & $17-22$ & $24-29$ & $32-38$ & $39-45$ \\
\hline \multirow{5}{*}{$\begin{array}{l}\text { Fermentation + } \\
\text { Liming }\end{array}$} & 1 & $0^{A b}$ & $0^{\mathrm{Bb}}$ & $539^{\mathrm{Bb}}$ & $28556^{\mathrm{Aa}}$ & $13661^{\mathrm{Aa}}$ & $4722^{\mathrm{Aa}}$ \\
\hline & 2 & $33^{A C}$ & $4644^{A b}$ & $4144^{A b}$ & $26383^{\mathrm{Aa}}$ & $14383^{\mathrm{Aa}}$ & $7328^{\text {Aa }}$ \\
\hline & 3 & $0^{A b}$ & $2011^{\text {Aa }}$ & $1750^{\mathrm{ABa}}$ & $10683^{\mathrm{Aba}}$ & $10394^{\mathrm{ABa}}$ & $18011^{\text {Aa }}$ \\
\hline & 4 & $28^{\mathrm{AC}}$ & $356^{\mathrm{ABbc}}$ & $439^{\mathrm{Bbc}}$ & $194^{\mathrm{Bbc}}$ & $4367^{\text {BCab }}$ & $7833^{\text {Aa }}$ \\
\hline & 5 & $6^{\mathrm{Ab}}$ & $28^{\mathrm{Bb}}$ & $2133^{A B a}$ & $261^{\text {Bab }}$ & $261^{\text {cab }}$ & $5556^{A a}$ \\
\hline \multirow[t]{5}{*}{ Liming } & 1 & $0^{\mathrm{Bb}}$ & $44^{A b}$ & $772^{\mathrm{Bb}}$ & $8733^{A b a}$ & $8050^{\text {Aa }}$ & $8244^{\mathrm{Aba}}$ \\
\hline & 2 & $10356^{\text {Aab }}$ & $861^{\mathrm{Ab}}$ & $6572^{\text {Aab }}$ & $13261^{\mathrm{Aa}}$ & $12906^{\text {Aab }}$ & $4161^{\mathrm{Bab}}$ \\
\hline & 3 & $28^{B C}$ & $50^{A C}$ & $544^{\mathrm{BC}}$ & $8278^{\mathrm{ABb}}$ & $2450^{\mathrm{Aba}}$ & $25900^{\text {Aa }}$ \\
\hline & 4 & $83^{\mathrm{Bb}}$ & $328^{A b}$ & $311^{\mathrm{Bb}}$ & $4706^{\mathrm{Ba}}$ & $1072^{\mathrm{Bab}}$ & $2728^{\text {вa }}$ \\
\hline & 5 & $122^{\mathrm{Bb}}$ & $294^{\mathrm{Ab}}$ & $922^{\mathrm{Bab}}$ & $1300^{\mathrm{Bab}}$ & $5200^{A B a}$ & $8822^{\mathrm{ABa}}$ \\
\hline \multirow[t]{5}{*}{ Fermentation } & 1 & $0^{A b}$ & $0^{A b}$ & $0^{\mathrm{Bb}}$ & $14194^{\mathrm{Aa}}$ & $4233^{\text {Aa }}$ & $10133^{\text {Аa }}$ \\
\hline & 2 & $78^{A b}$ & $111^{\mathrm{Ab}}$ & $6033^{\text {Aa }}$ & $4217 \mathrm{Aa}$ & $12472 \mathrm{Aa}$ & $10856 \mathrm{Aa}$ \\
\hline & 3 & $1139^{A b c}$ & $261^{A b c}$ & $128^{B C}$ & $283^{\mathrm{Bbc}}$ & $3289^{A b}$ & $21683^{\text {Aa }}$ \\
\hline & 4 & $39^{\mathrm{Aa}}$ & $6^{\mathrm{Aa}}$ & $61^{\mathrm{Ba}}$ & $11^{\mathrm{Ba}}$ & $328^{\mathrm{Ba}}$ & $3178^{\text {ва }}$ \\
\hline & 5 & $17^{\mathrm{Ab}}$ & $28^{\mathrm{Ab}}$ & $122^{\mathrm{Bb}}$ & $461^{\text {Bab }}$ & $3739^{\text {Аa }}$ & $3156^{\mathrm{Ba}}$ \\
\hline
\end{tabular}

Uppercase letters compare flocks within each age, and lowercase letters compare age within each flock for each sanitary treatment by Tukey test $(p \leq 0.05)$.

Primarily it was executed an DNA extraction from vaccine as described by Tang et al. (2018) with amplifications of six species of the genus Eimeria present in the vaccine (Line 4 - E. acervulina - 811 bp; Line 5 - E. brunetti - 626 bp; Line 6 - E. tenella - 539 bp; Line 7 - E. mitis - 460 bp; Line 8 - E. praecox - 354 bp; Line 9 - E. maxima - 272 bp), except 
E. necatrix, absent in Mix 2 (line 2) and in individual reaction (line 10) (Figure 4). The next step was to perform an DNA extraction from field samples, however the first attempt was unsuccessful, so it became necessary to do an adaptation in the extraction process.
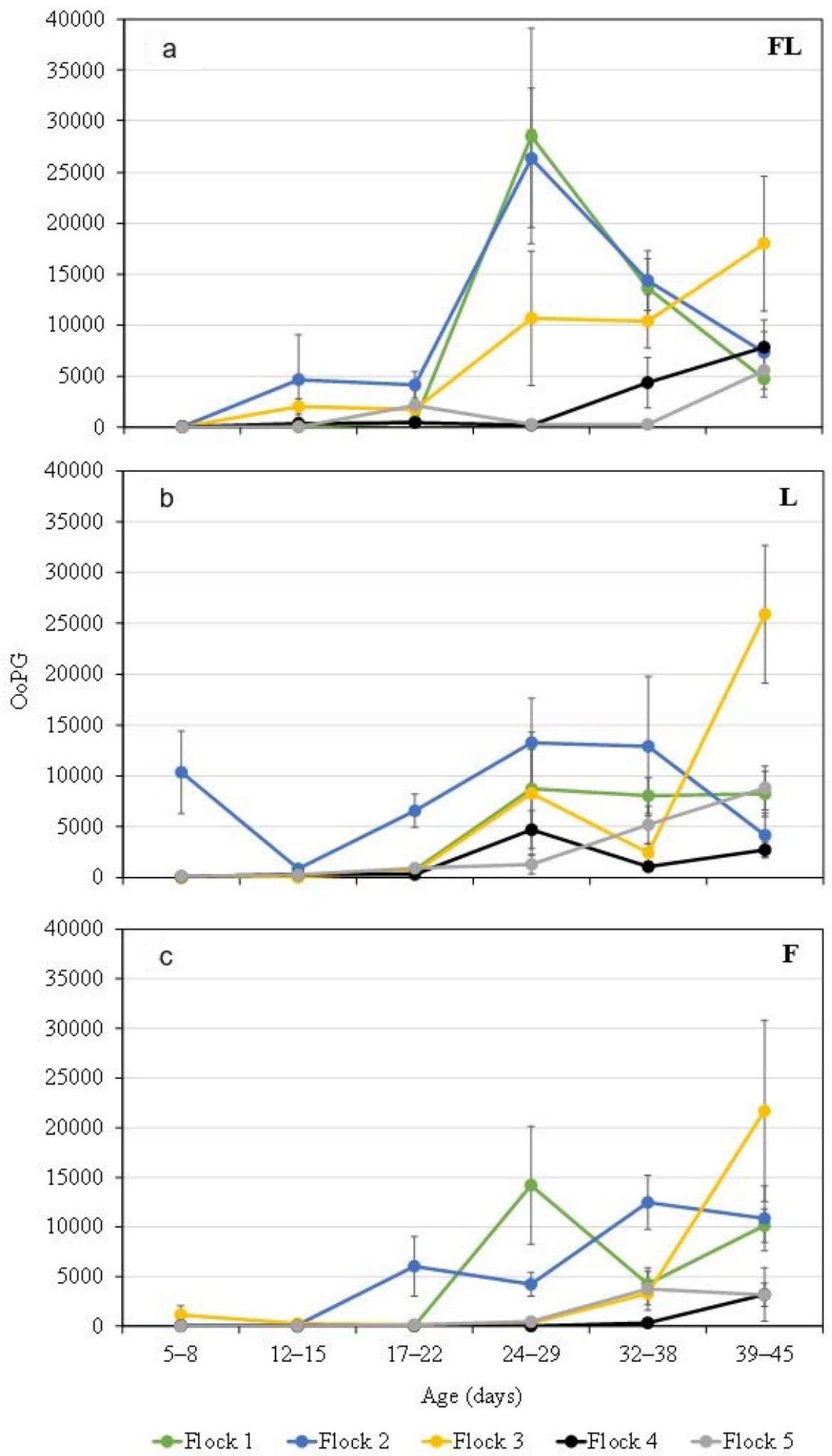

Figure 3. Dynamics of Eimeria spp. oocysts excretion at each age and flock on litter treated by fermentation + liming (FL), liming $(L)$ or fermentation (F) in commercial aviaries in the Western region of Paraná, Brazil. 
It was chosen to recover oocysts from samples using the principle of flotation in saturated salt solution as described by Willis (1921) (Figure 5), followed by an extraction according to the protocol already used with the vaccine. It was identified amplification in line 6 for E. praecox (354 bp) in Mix 2.

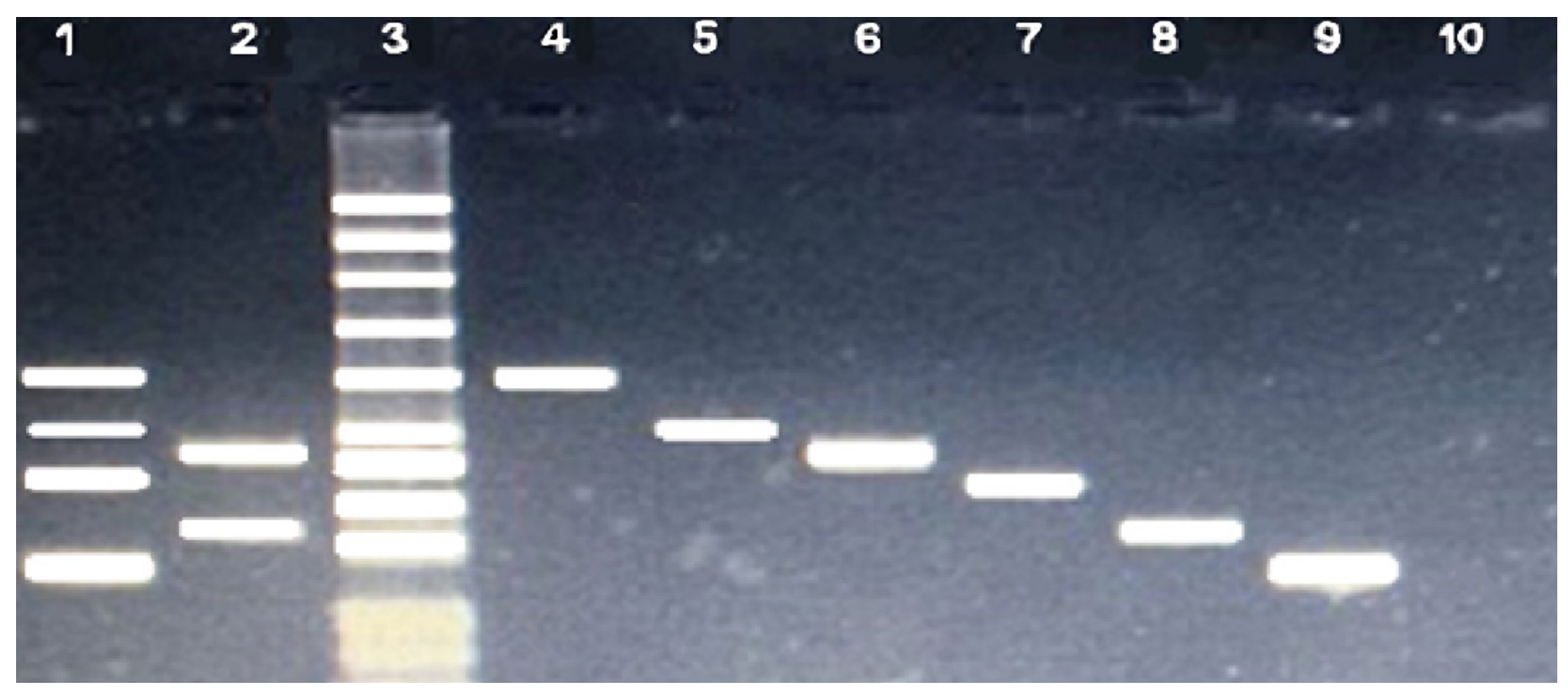

Figure 4. Standardization of the Multiplex PCR test to detect Eimeria spp. made with vaccine. Electrophoresis in an $2.5 \%$ agarose reaction in a $25 \mu \mathrm{L}$ reaction, with $0.5 \mu \mathrm{L}$ of each primer, $1 \mu \mathrm{L}$ of sample and alteration of the combined primers. Line 1 - Mix 1 (E. acervulina - 811 bp, E. brunetti - 626 bp, E. mitis - 460 bp and E. maxima - 272 bp); Line 2 - Mix 2 (E. tenella - 539 bp, E. praecox - 354 bp); Line 3 - Molecular weight marker; Line 4 - E. acervulina - 811 bp; Line 5 - E. brunetti - 626 bp; Line 6 - E. tenella - 539 bp; Line 7 - E. mitis - 460 bp; Line 8 - E. praecox - 354 bp; Line 9 - E. maxima - 272 bp; Line 10 - E. necatrix - 200bp.

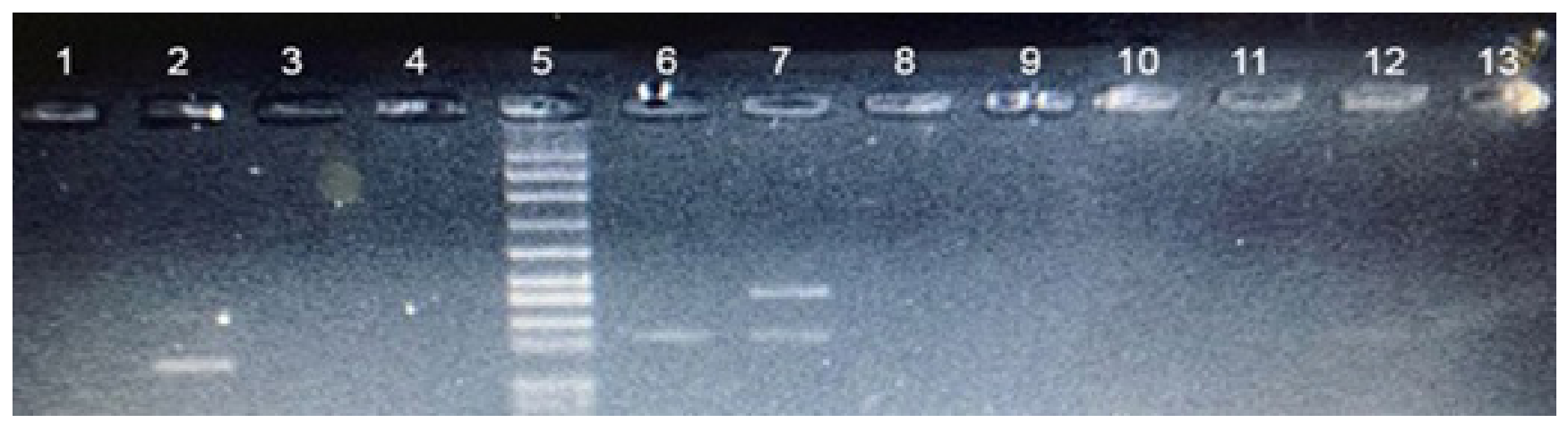

Figure 5. PCR reaction for the modified purification process of collected samples. Electrophoresis in an $2.5 \%$ agarose reaction in a $25 \mu \mathrm{L}$ reaction, with $0.5 \mu \mathrm{L}$ of each primer, $1 \mu \mathrm{L}$ of sample and alteration of the primer configuration. Line 1 - precipitate from field sample for mix 1; Line 2 - C + Multiplex 1 (E. acervulina - 811 bp, E. brunetti - 626 bp, E. mitis - 460 bp and E. maxima - 272 bp); Line 3 - Positive control for Mix 1; Line 4 - field sample supernatant for Mix 1; Line 5 - Molecular weight marker; Line 6 - precipitate from field sample for Mix 2; Line 7 - Positive control for Mix 2 (E. tenella - 539 bp, E. praecox - 354 bp); Line 8 - Negative control for Mix 2; Line 9 - field sample supernatant for Mix 2; Line 10 to 13 - field samples processed according to Pereira et al. (2008).

\section{Discussion}

All the effects and interactions where significant, except the interaction between litter treatment $x$ collection points, such as represented in Table 1.

The shedding of oocysts is directly dependent on the activity of the protozoan, which begins at the end of the pre-patent period, as was also evidenced by Zulpo et al. (2007) when analyzing artificially infected birds. The use of OoPG as a method of evaluating treatment efficiency, based on the reproductive behavior of different Eimeria, demonstrated to be directly proportional to the viability of the pathogens (Chasser et al., 2020). Lillehoj \& Ruff (1987) showed the importance of the dose of oocyst infection to cause harm in birds, and the reproductive capacity and the elimination of oocysts was linked to the treatments evaluated. Initially, in this experiment, there was a 
low amount of oocysts eliminated by birds at the $5^{\text {th }}$ day of life, emphasizing the importance of the environment in the birds primary infection. Then, there was a drop in OoPG values, and a second peak was expressed between $24^{\text {th }}$ and $38^{\text {th }}$ days, due to reinfection, followed by stabilization in the three treatments, showing the efficiency in reducing the reduction of oocysts, with low difference $(p<0.0001)$, in relation to the age of the birds (Figure 1$)$. This peak was also observed by Chapman et al. (2016) in a study carried out with poultry, in which the peak was found between the $20^{\text {th }}$ and $33^{\text {th }}$ days. After the $30^{\text {th }}$ day, there was a reduction and stabilization of OoPG levels between $8 \times 10^{3}$ and $1 \times 10^{4}$ oocysts/g. In litter treatments where liming $(L)$ and fermentation $(F)$ were used, there were no peaks as evident as the treatment where the association of liming and fermentation (FL) was adopted, which can be related to lower oocyst intake viable that did not develop sufficiently to achieve sporulation and consequently had less significant peaks. Wallach (2010) evidenced that between the $5^{\text {th }}$ and $20^{\text {th }}$ life of the birds, there is a period of coccidium peaking, moment of reinfection where sporulated oocysts from first shedding, present in the litter was ingested by birds a second time, and this second peak may vary in its intensity according to the species of of the genus Eimeria and quantity of sporulated oocysts ingested, identified in the present study, by the progressive increase in OoPG. Williams (2001) infected artificially individuals of Gallus gallus and demonstrated peak periods that varied between 5 and 17 days, depending on the amount of oocysts administered. According to Fayer (1980), it is important to recognize the diapause phases that can interact in natural coccidial infections. The fermentation process promotes the heating of the litter and can reach a temperature between $50-70^{\circ} \mathrm{C}$, being the main tool in the control of pathogens (CLSA, 1995). The results demonstrate that the fermentation (F) obtained the best results, in relation to the number of oocysts shedding (3,833 OoPG) when evaluating the period between $24^{\circ}$ and $29^{\circ}$ days, when compared to the treatments of the association of liming with fermentation (FL) and liming (L), with 13,216 and 7,256 OoPG respectively. For Eimeria, high temperatures, reduced oxygen saturation and a drop in humidity below $25 \%$ are harmful to the protozoan to sporulated. Liming $(L)$ showed a result close to fermentation (F) between the $24^{\text {th }}$ and $29^{\text {th }}$ days ( 7256 and 3833 , respectively). The association of treatments (FL), on the other hand, showed a worse result with an increase in the values for counting oocysts (13,216 OoPG) (Table 2).

The lower performance of the combined treatments (FL) in reducing oocysts in litter may be linked to an antagonistic effect among treatments (Figure 1). The individual treatments were efficient in controlling Salmonella and Clostridium by reducing humidity, changing $\mathrm{pH}$ and, considering that fermentation also occurs in temperature control. It is important to highlight that the fermentation process acidifies the $\mathrm{pH}$ of the litter, while liming alkalizes the $\mathrm{pH}$ and reduces the production of methane, consequently the bacterial activity (Kelleher et al., 2002; Silva et al., 2007). The residual effect of the fermentative treatment can be affected by the addition of lime, the elevation of acidic $\mathrm{pH}$ to a pH between neutral and alkaline, which has no sanitizing action for the main groups of microorganisms that are pathogenic to birds.

Garcés-Gudiño et al. (2017) evaluated the microbiological composition in first, second and third use poultry litter and determined that the first use litter is the most contaminated, these authors highlighted the hypothesis that the contamination was diluted with organic matter. In this research, evaluating five successive uses, it was found that the count of oocysts had interaction with other factors, since even with a greater number of flock observed, there was a reduction of oocysts regardless of the treatment used, considering that in the fourth and in the fifth flock, the litter was composed almost entirely of organic matter.

In all treatments, interaction with the cycles was observed $(p<0.0001)$, with the second cycle being the period with the highest OoPG value for the three treatments, with a peak for the treatment associated liming with fermentation. Among the evaluated treatments, fermentation (F) obtained the lowest average of oocysts eliminated in all evaluated production cycles as described in Table 3 (Figure 2).

It is important to highlight that the initial contamination of the poultry houses exists, as well as the progressive drop in the number of oocysts (Costa et al., 2000; Chapman et al., 2016). The first and second flocks showed a higher level of contamination by oocysts, which may be linked to residual contamination of the previous flock. It should be considered that the litter is placed over dirt in the aviary, which makes it difficult to control this type of surface, enabling the protozoan to be maintained in the environment oocysts of Eimeria, even in hygienic sheds and when changing litters. It was identified soon in first evaluations. Control difficulties were associated with contaminated fomites, equipment or clothing and with contaminated structures (Chapman et al., 2016; Garcés-Gudiño et al., 2017). When performing OoPG analyzes, the first positive reading for Eimeria occurred in $17^{\text {th }}$ day of the first flock in the three treatments. In the previous collections of the $5^{\text {th }}$ and $12^{\text {th }}$ days they were negative and in the subsequent flock there were positive results regardless of age, highlighting the difficulty in controlling the agent. 
The climatic factor was also important, in the first and second flock occurred during the autumn and winter period, where although the ambient temperature is not favorable to the sporulation of oocysts, the high animal density and heating system, raise the temperature of the warehouses, in addition to reduced use of forced ventilation, which leads to less air renewal and moisture removal. The hypothesis that the accumulation of organic matter causes the dilution of microorganisms is also raised (Carvalho et al., 2011; Chapman et al., 2016; Garcés-Gudiño et al., 2017). However, none of the studies evaluated litter treatment methods. Birds evaluated in cages to determine the efficiency of coccidiosis control by coccidiostatic and coccidiocidal molecules report that the substrate increased its contamination until the fourth reuse (Costa et al., 2000).

The behavior observed reiterates that the first infer fundamental role in the contamination of subsequent litters, mainly up to the third flock. The drop in the average OoPG values with the progression of the use of the litter in subsequent flock could be associated with the treatments $(p=0.0006)$, observed mainly in the period between the $24^{\text {th }}$ and the $38^{\text {th }}$ days by the progressive drop in the OoPG, which corroborate with Lillehoj \& Ruff (1987), and Chasser et al. (2020), the average oocyst elimination and analyses are described in Table 4. FL showed the natural behavior of the protozoan with a peak between $25^{\text {th }}$ and $35^{\text {th }}$ days, as expected (Figure 3a). For individualized treatments, the peaks of elimination of oocysts were much smaller, mainly observed in the first two flock evaluated (Figure 3b and 3c).

Poultry housing are built to enable birds to develop their maximum zootechnical capacity, under adequate environment, health and nutrition. The interaction between collection points and treatment were not significant in terms of oocyst count $(p=0.5143$ ) (Table 2$)$, although there was a visual difference between the points, where P1 was cleaner with less dirt particles in the lines of feeders and drinkers, probably due to the particle dragging dust and feathers of the birds and also by the water deposit from the sprinklers, while points P2 and P3 accumulated a greater amount of organic matter and dust in the suspension lines of the structures, railings and walls inside the building.

Determine the Eimeria developing in poultry is essential to establish an adequate method of coccidiosis control. Moraes et al. (2015), stablished the prevalence of Eimeria in 250 properties in the State of Santa Catarina, in Southern Brazil, where E. maxima (63.7\%), E. acervulina (63.3\%) and E. tenella (54.6\%) are the most prevalent. For this, the use of tools such as PCR Multiplex can become a great ally in the determination of species circulating, as it allows that in just one reaction identify more than one species reducing the cost and time. Oocyst recovery and clarification were performed according to Tang et al. (2018) and the phenol-chloroform extraction protocol as described in Sambrook et al. (1989). The amplification of the positive control with the combination of the primers, in 2 mixes, was effective as shown in Figure 4, with no amplification for E. necatrix, which may be due to incompatibility of the primer with the strain used in the vaccine, as observed by Lew et al. (2003).

There were difficulties in extracting genetic material from field samples, mainly due to the presence of a large amount of bacteria, microorganisms and non digested proteins in feces. Thus, in order to improve the quality of the samples, extractions were carried out with modification in the recovery of oocysts from samples to optimize the amount of DNA recovered. The PCR reaction obtained shows that in field samples recovered with the proposed protocol, a band compatible with E. praecox (line 6 - 354 bp) was formed (Figure 5).

\section{Conclusion}

Sanitary management of litter is essential factor in the control of coccidiosis throughout successive flocks and is subject to interaction between the host and Eimeria and other factors such as flock, age, treatment and their interactions. The use of only one treatment, especially fermentation, proved to be more efficient than the combination of treatments to control Eimeria in addition to simplifying handling and being low cost. Beside this result, Multiplex PCR as a species identification technique proved to be efficient as observed in vaccine extraction to obtain positive control. Fecal samples collected from the field require a new methodology for purification and recovery of oocysts in the search for promising results for future use in species identification.

\section{Acknowledgements}

This paper was developed only and exclusively by its authors without financial assistance of any institution or company. 


\section{References}

Adhikari P, Kiess A, Adhikari R, Jha R. An approach to alternative strategies to control avian coccidiosis and necrotic enteritis. J Appl Poult Res 2020; 29(2): 515-534. http://dx.doi.org/10.1016/j.japr.2019.11.005.

Carvalho FS, Wenceslau AA, Teixeira M, Albuquerque GR. Molecular diagnosis of Eimeria species affecting naturally infected Gallus gallus. Genet Mol Res 2011; 10(2): 996-1005. http://dx.doi.org/10.4238/vol10-2gmr1043. PMid:21710449.

Chapman HD, Barta JR, Hafeez MA, Matsler P, Rathinam T, Raccoursier M. The epizootiology of Eimeria infections in commercial broiler chickens where anticoccidial drug programs were employed in six successive flocks to control coccidiosis. Poult Sci 2016; 95(8): 1774-1778. http://dx.doi.org/10.3382/ps/pew091.

Chasser KM, Duff AF, Wilson KM, Briggs WN, Latorre JD, Barta JR, et al. Research Note: evaluating fecal shedding of oocysts in relation to body weight gain and lesion scores during Eimeria infection. Poult Sci 2020; 99(2): 886-892. http://dx.doi.org/10.1016/j. psj.2019.10.028. PMid:32036984.

College for Agriculture and Life Science - CLSA. The composting process [online]. 1995 [cited 2021 Apr 2]. Avaible from: https:// cals.arizona.edu/ kittfp/factsheets.html

Costa CAF, Guidoni AL, Paiva DP, Ávila VS. Coccidiosis and performance in broilers with anticoccidial medicated feed starting at different ages. Arq Bras Med Vet Zootec 2000; 52(2): 144-149. http://dx.doi.org/10.1590/S0102-09352000000200010.

Fayer R. Epidemiology of protozoan infections: the coccidia. Vet Parasito/ 1980; 6(1-3): 75-103. http://dx.doi.org/10.1016/03044017(80)90039-4.

Garcés-Gudiño J, Merino-Guzmán R, Cevallos-Gordón AL. Litter reuse reduces Eimeria spp oocyst counts and improves the performance in broiler chickens reared in a tropical zone in Ecuador. Eur Polit Sci 2017; 82(1): 1-9. http://dx.doi.org/10.1399/ eps.2018.220.

Gazoni FL, Adorno FC, Matte F, Alves AJ, Campagnoni IDP, Urbano T, et al. Correlation between intestinal health and coccidiosis prevalence in broilers in Brazilian agroindustries. Parasitol Int 2020; 76(1): 102027. http://dx.doi.org/10.1016/j.parint.2019.102027. PMid:31756388.

Gordon H, Whitlock HV. A new technique for counting nematode eggs in sheep faeces. J Counc Sci Ind Res 1939; $12(1)$ : $50-52$.

Kawazoe U. Coccidiose. In: Berchieri A Jr, Silva EN, Di Fábio J, Sesti L, Zuanaze MAF, editors. Doenças das aves. 2. ed. Campinas: FACTA; 2009. p. 837-855.

Kelleher BP, Leahy JJ, Henihan AM, O'Dwyer TF, Sutton D, Leahy MJ. Advances in poultry litter disposal technology: a review. Bioresour Technol 2002; 83(1): 27-36. http://dx.doi.org/10.1016/S0960-8524(01)00133-X. PMid:12058828.

Lew AE, Anderson GR, Minchin CM, Jeston PJ, Jorgensen WK. Inter- and intra-strain variation and PCR detection of the internal transcribed spacer 1 (ITS-1) sequences of Australian isolates of Eimeria species from chickens. Vet Parasitol 2003; 112(1-2): 33-50. http://dx.doi.org/10.1016/S0304-4017(02)00393-X. PMid:12581583.

Lillehoj HS, Ruff MD. Comparison of disease susceptibility and subclass-specific antibody response in SC and FP chickens experimentally inoculated with Eimeria tenella, E. acervulina, or E. maxima. Avian Dis 1987; 31(1): 112-119. http://dx.doi. org/10.2307/1590782. PMid:3579780.

MacDonald SE, van Diemen PM, Martineau H, Stevens MP, Tomley FM, Stabler RA, et al. Impact of Eimeria tenella Coinfection on Campylobacter jejuni colonization of the chicken. Infect Immun 2019; 87(2): 1-12. http://dx.doi.org/10.1128/IAl.00772-18. PMid:30510107.

Moraes JC, França M, Sartor AA, Bellato V, Moura AB, Magalhães MLB, et al. Prevalence of Eimeria spp. in broilers by Multiplex PCR in the southern region of Brazil on two hundred and fifty farms. Avian Dis 2015; 59(2): 277-281. http://dx.doi.org/10.1637/10989112014-Reg. PMid:26473679.

Peek HW, Landman WJM. Coccidiosis in poultry: anticoccidial products, vaccines and other prevention strategies. Vet Q 2011; 31(3): 143-161. http://dx.doi.org/10.1080/01652176.2011.605247. PMid:22029884.

Pereira JT, Costa AO, Silva MBO, Schuchard W, Osaki SC, Castro EA, et al. Comparing the Efficacy of Chlorine, Chlorine Dioxide, and Ozone in the Inactivation of Cryptosporidium parvum in Water from Parana State, Southern Brazil. Appl Biochem Biotechnol 2008; 151(2-3): 464-473. http://dx.doi.org/10.1007/s12010-008-8214-3. PMid:18498060.

Rimet CS, Maurer JJ, Berghaus RD, Jordan BJ, Silva LHA, Stabler LJ, et al. The contribution of Eimeria Coinfection and intestinal inflammation to cecal colonization and systemic spread of Salmonella typhimurium deficient in tetrathionate reductase or type III secretion systems Salmonella pathogenicity island 1 or 2. Avian Dis 2019; 63(4): 559-567. http://dx.doi.org/10.1637/ aviandiseases-D-19-00082. PMid:31865669.

Ruggiero MA, Gordon DP, Orrell TM, Bailly N, Bourgoin T, Brusca RC, et al. A higher level classification of all living organisms. PLoS One 2015; 10(6): e0130114. http://dx.doi.org/10.1371/journal.pone.0130114. PMid:26068874. 
Sambrook J, Fritcsh EF, Maniatis T. Molecular cloning: a laboratory manual. 2nd ed. Nova lorque: Cold Spring Harbor Laboratory; 1989.

Santos JI Fo, Talamini DJD, Martins F. Conjuntura econômica da avicultura brasileira. Anuário 2020 da Avicultura Industrial 2019 1294(11): 14-20.

SAS Institute. Statistical Analysis System (SAS) user's guide for Windows: Statistics, version 9.0. Cary: SAS Institute Inc.; 2002.

Silva VS, Rech DV, Coldebella A, Bosetti N, Avila VS. Efeito de Tratamentos Sobre a Carga Bacteriana de Cama de Aviário Reutilizada em Frangos de Corte. Concórdia: Embrapa Suínos e Aves; 2007. Comunicado Técnico.

Tang X, Huang G, Liu X, El-Ashram S, Tao G, Lu C, et al. An optimized DNA extraction method for molecular identification of coccidian species. Parasitol Res 2018; 117(3): 655-664. http://dx.doi.org/10.1007/s00436-017-5683-8. PMid:29396674.

Urquhart GM, Armour J, Duncan JL, Jenning FW. Protozoologia veterinária. In: Urquhart GM, Armour J, Duncan JL, Jennings FW, editors. Parasitologia veterinária. Rio de Janeiro: Guanabara Koogan; 1998. p. 196-203.

Wallach M. Role of antibody in immunity and control of chicken coccidiosis. Trends Parasito/ 2010; 26(8): 382-387. http://dx.doi. org/10.1016/j.pt.2010.04.004. PMid:20452286.

Williams RB. Quantification of the crowding effect during infection with the seven Eimeria species of the domesticated fowl: its importance for experimental designs and the production of oocyst stocks. Int J Parasitol 2001; 31(10): 1056-1069. http://dx.doi. org/10.1016/S0020-7519(01)00235-1. PMid:11429169.

Willis HH. A simple levitation method for the detection of hookworm ova. Med J Aust 1921; 2(18): 375-376. http://dx.doi. org/10.5694/j.1326-5377.1921.tb60654.x.

Zhang JJ, Wang LX, Ruan WK, An J. Investigation into the prevalence of coccidiosis and maduramycin drug resistance in chickens in China. Vet Parasitol 2013; 191(1-2): 29-34. http://dx.doi.org/10.1016/j.vetpar.2012.07.027. PMid:22925822.

Zulpo DL, Peretti J, Ono LM, Longhi E, Oliveira MR, Guimarães IG, et al. Patogenicidade e observações histopatológicas de frangos de corte infectados experimentalmente com isolados de Eimeria tenella, E. acervulina e E. maxima. Semina: Ciênc Agrár 2007; 28(1): 97-104. http://dx.doi.org/10.5433/1679-0359.2007v28n1p97. 